Western University Scholarship@Western

1983

\title{
Childlessness in Canada 1971: A Further Analysis
}

Nigel Tomes

Follow this and additional works at: https://ir.lib.uwo.ca/economicsresrpt

Part of the Economics Commons

Citation of this paper:

Tomes, Nigel. "Childlessness in Canada 1971: A Further Analysis." Department of Economics Research Reports, 8311. London, ON: Department of Economics, University of Western Ontario (1983). 
ISBN: $0-7714-0416-6$

RESEARCH REPORT 8311

\section{CHILDIESSNESS IN CANADA 1971 :}

A FURTHER ANALYSIS*

by

Nigel Tomes

University of Western Ontario and

Economics Research Center/NORC

Deperinent of Econonice lipheng

(7) 5 is 1989

4hitersity of

April, 1983

* Monica van Huystee provided competent research assistance. Chris Robinson gave helpful advice. The usual caveat applies. 


\begin{abstract}
This paper re-examines the correlates of childlessness in Canada, using a maximum likelihood probit estimation technique. Contrary to the conclusions of Grindstaff, Balakrishnan and Ebanks, we find that selected ascribed attributes (religion and nativity) and achieved characteristics (labour force status, schooling and/or family income) are significant correlates of childlessness, both for younger and older cohorts of women. Locational differences are also evident, particularly among older women (45+). Marriage duration is an important determinant of childlessness, especially among women who have been married relatively few years. Previous research is extended by analyzing the interaction between labour force status and childlessness, taking into account self-selection in labour force participation. The determinants of childlessness differ between working and non-working women and husband's and wife's incomes operate in opposing directions.
\end{abstract}




\section{Introduction}

In a recent paper professors Grindstaff, Balakrishnan and Ebanks (1981) (hereafter G, B E) examined the socio-demographic correlates of childlessness using data from the 1971 Canadian Census. They conclude that the "ascribed characteristics of ever-married women (religion, ethnicity, mother tongue, home language and place of birth.) provide no meaning ful associations to childlessness" (p. 337). Using a multivariate analysis they find that "factors associated with childlessness are certain achieved variables (labour force participation and educational attainment) and they are only significant among the younger age cohorts" (p. 347). "At ages over 30, the only variable that has an important impact (on childlessness) is marriage duration" (p. 347). "The overall findings in [their] study suggest that...differentials in childlessness are no longer readily observable among the married women living in Canada in the 1970's" (p. 350). Based on their study it would appear that among women $30+$ of a given marriage duration, childlessness is a random event.

These findings stand in stark contrast to the earlier analysis of fertility by the same authors, using the same data (Balakrishnan et al, 1979, p. 201, pp. 205-7) where both ascribed and achieved characteristics were found to be significant correlates of the number of children ever born to married women in all age categories. Previous investigators using Canadian Census data (e.g., Wolowyñ a, 1977) reported a negative and significant relationship between income and childlessness. Moreover, a recent analysis of Canadian fertility, by Carliner, Robinson and Tomes (1980) also examines the determinants of childlessness (see Carliner et al, 1980, Table 2, equation (1), p. 56). These authors find that for women age 35+, the probability of childlessness is significantly related to educational attainment, language, religion and urban/rural location. In their study of older women, Carliner et al find that higher education increases the probability of childlessness, French 
mother tongue women are more likely to be childless than English mother tongue women, and Roman Catholics and women residing in rural areas have a lower probability of having no children than women who are non-Catholic and urban. ${ }^{1}$ These results contrast with the conclusion reached by $G, B$ \& that for women women $35+$ only marriage duration enters significantly as a correlate of childlessness ( $G$, B \& E, Table 5, pp. 348-9).

Differences between these two studies may explain these conflicting conclusions. Although both studies analyze data from the 1971 Canadian Census, the list of regressors differs substantially. ${ }^{2}$ Both sets of researchers include religion, region of residence in 1971, urban/rural location and education. G, B E also include work status, ethnicity, migration status and marriage duration, variables not considered by Carliner et al. The inclusion of the latter variable--marriage duration--may account for the divergent findings since in the G, B E study it is the most important determinant of childlessness and is expected to be correlated with both ascribed and acquired characteristics. In contrast to the use of family income by G, B \& E, Carliner, et al use a measure of the husband's wage and the non-labour income of the family (excluding earnings). Lastly, while G, B \& E use a Multiple Nominal Analysis (MNA) technique which treats all variables as categorical, Carliner et al use maximum likelihood logit and introduce education, wages and income as continuous variables.

The purpose of this paper is to re-examine the determinants of childlessness in Canada. In the following section we argue that maximum likelihood techniques are preferable to Multiple Nominal Analysis. Section III reports the results of re-estimating the model of $G, B$ \& $E$ using multivariate maximum likelihood probit. Further, in Section IV we re-examine whether the results 
obtained by Carliner et al are sensitive to the inclusion of the important demographic variable: marriage duration. Section $V$ advances previous analyses by examining the interaction between women's labour force status and childlessness. Neither of the two previous studies adequately address this issue. G, B \& E include measures of the women's past and present labour force status among their regressors, despite the fact that labour force status and fertility are, in principle, simultaneously determined endogenous variables. Carliner, et al assume that all women enter the labour force at some point in their lifetime (p. 48), an assumption not supported by the data (see Robinson and Tomes, 1982). Section V, the major contribution of this paper, employs recently developed techniques which recognize that labour force status is subject to individual choice, while analyzing the determinants of childlessness among working and non-working women. We find marked differences in the correlates of childlessness between women who differ in their labour force status. Furthermore, the effects of husband's and wife's incomes on child-lessness display pronounced differences; implying that it is inappropriate to aggregate the incomes of household members into "family income". The final section presents a brief summary and conclusions.

\section{Alternative Statistical Procedures}

The Multiple Nominal Analysis technique (MNA) employed by G, B E is an application of ordinary least squares (OLS) in which both the dependent and independent variables are dichotomous (Andrews and Messenger, 1973, Chapter 3). As a mitivariate technique MNA permits a more detailed analysis than crosstabulations and simple bivariate correlations. However, it is widely known that the application of oLS to the case of a dichotomous (dummy) dependent variable yields inefficient estimates and imprecise predictions. The use of dummy independent variables avoids the problem of predicted probabilities outside the unit interval, which arises when some of the independent variables are 
contimous (Andrews and Messenger 1973: 30). However, the problems of heteroscedastic errors and the non-normal distribution of residuals remain, so that the multiple $\mathrm{R}^{2}$ is no longer meaning ful and estimated standard errors are biased. Therefore the usual tests of significance are invalid (Nerlove and Press 1973,: 3-9). Notably the authors of MNA make no claims that their significance tests are consistent. ${ }^{3}$ Nerlove and Press also point out that least squares estimates are likely to be sensitive to the distribution of observations between cells. Andrews and Messenger recommend that the use of MNA be restricted to applications in which "each category of the dependent variable include(s) at least $10 \%$ of the cases" (p. 47). The problems outlined above are likely to be of considerable importance to the application of MNA by $G, B \& E$, since in the overall sample $16 \%$ of women are childless and in the three age cohorts $30-44$ less than $10 \%$ of women have no children. Since most of the problems associated with linear regression techniques in the presence of dichotomous dependent variables apply equally to MNA, alternative non-linear maximum likelihood techniques such as probit and logit (see Nerlove and Press, 1973; Amemiya, 1981) are to be preferred. Since probit and logit techniques in most applications yield similar results (Amemiya, 1981; Powers et al, 1978), the choice between the two is mainly a matter of convenience. In this paper we employ maximum likelihood probit which takes account of the dichotomous nature of the dependent variable and is capable of handling both continuous and dumy independent variables.

\section{The Socio-Demographic Correlates of Childlessness}

Our initial task is to re-estimate the empirical model of Grindstaff et al using maximum likelihood techniques. The sample employed is identical to that of G, B \& E: all ever-married women $15+$ from the $1 \%$ sample of individual files from the 1971 Canadian Census $(n=46,376)$. The variables examined are the same: age, marriage duration, education, family income, labour force participation, region and urban/rural location 1971, religion, 
ethnicity, nativity, language (mother tongue and language of the home) and migration status 1966-71. The first four of these variables are treated as continuous. ${ }^{4}$ clearly, age and marriage duration are both continuous with ranges 15-106 and 0-76 years, respectively, in the whole sample. Treating these variables as continuous, rather than in broad categories, allows for within-category variation in age and marriage duration to affect the incidence of childlessness. For example, G, B \& E code marriage duration into four categories: $<5,5-9,10-14,15+$ years. However, we find that even among teenage women $(15-19)$, all of whom have been married less than 5 years, variations in the duration of marriage influence significantly the probability of being without children. Total family income in the original data is coded in 30 categories and can be treated as continuous for our purposes, using interval mid-points. We use this variable (FAMINC) rather than the 5-category classification employed by G, B \& E. Finally, the education variable, which in the original data contains 12 categories, was coded as a continuous variable (YRSSCH) after making assumptions regarding the number of years normally required to achieve a given level of education attainment. 5

Although age, marriage duration, income and education are treated as continuous, there is nothing inherent in our statistical procedures that requires these variables to enter the probit function linearly. By introducing squared, cubed and higher-order polynomial terms a wide variety of functional relationships can be captured, including U-shaped and inverted-U relations. Our procedure was to introduce successively higher order polynomial terms until they failed to reach the statistical criterion of significance at the $10 \%$ level. 6

Empirical Results :

Table 1 reports the empirical results of a multivariate probit analysis of childlessness for the whole sample and separately for various age groups.? Let us consider first the results reported in column (1) for the whole sample. Both AGE and AGESQ enter with statistically significant coefficients. The 
TABLE 1: The Correlates of Childlessness: Probit Regressions

\begin{tabular}{|c|c|c|c|c|c|c|c|c|}
\hline Reg. No.- & (1) & (2) & (3) & (4) & (5) & (6) & (7) & (8) \\
\hline Sample & All Ages & Age $15-19$ & $20-24$ & $25-29$ & $30-34$ & $35-39$ & $40-44$ & $45+$ \\
\hline \multicolumn{9}{|l|}{$\begin{array}{l}\text { Independent } \\
\text { Variables }\end{array}$} \\
\hline AGE & $\begin{array}{c}0.00685 \\
{[6.565]}\end{array}$ & $\begin{array}{c}0.040 \\
{[1.699]}\end{array}$ & $\begin{array}{r}.0227 \\
{[3.355]}\end{array}$ & -- & $\begin{array}{r}.0057 \\
{[2.469]}\end{array}$ & {$[3.746]$} & -- & {$[9.02905$} \\
\hline AGESQ & $\begin{array}{l}0.0000666 \\
{[6.140]}\end{array}$ & -- & -- & $\cdots$ & -- & -- & -- & $\begin{array}{c}-.0001378 \\
{[5.619]}\end{array}$ \\
\hline \multicolumn{9}{|l|}{$\begin{array}{l}\text { Marriage } \\
\text { Duration }\end{array}$} \\
\hline MD & $\begin{array}{c}-0.09785 \\
{[41.797]}\end{array}$ & $\begin{array}{l}-0.489 \\
{[7.445]}\end{array}$ & $\begin{array}{r}-.2284 \\
{[16.075]}\end{array}$ & $\begin{array}{r}-.0953 \\
{[15.614]}\end{array}$ & $\begin{array}{r}-.0464 \\
{[6.548]}\end{array}$ & $\begin{array}{l}-.01556 \\
{[6.425]}\end{array}$ & $\begin{array}{c}-.02525 \\
{[9.173]}\end{array}$ & {$\left[\begin{array}{c}-.01470 \\
{[14.600]}\end{array}\right.$} \\
\hline MDSQ & $\begin{array}{c}0.00653 \\
{[24.740]}\end{array}$ & $\begin{array}{c}0.074 \\
{[2.850]}\end{array}$ & $\begin{array}{r}.0138 \\
{[6.077]}\end{array}$ & {$[8.00434$} & {$[3.00294$} & {$[2.1887]$} & {$\left[\begin{array}{c}.000497 \\
{[5.668]}\end{array}\right.$} & {$[2.000039$} \\
\hline $\mathrm{MD}^{3}$ & $\begin{array}{l}-0.000222 \\
{[18.073]}\end{array}$ & -- & -- & -- & {$\left[\begin{array}{l}-.000076 \\
{[2.222]}\end{array}\right.$} & -- & -- & - \\
\hline $\mathrm{MD}^{4}$ & $\begin{array}{l}0.348 \times 10^{-5} \\
{[14.275]}\end{array}$ & $\cdots$ & -- & -- & -- & -- & $-\infty$ & -- \\
\hline $\mathrm{MD}^{5}$ & $\begin{array}{l}-0.205 \times 10^{-7} \\
{[11.928]}\end{array}$ & -- & -- & -- & -- & $\cdots$ & -- & -- \\
\hline \multicolumn{9}{|l|}{ Education } \\
\hline YRSSCH & $\begin{array}{l}-0.0114 \\
{[5.324]}\end{array}$ & $\begin{array}{l}-0.097 \\
{[2.309]}\end{array}$ & $\begin{array}{r}-.0780 \\
{[4.962]}\end{array}$ & {$[.00104$} & -.000399 & $\begin{array}{r}-.00840 \\
{[1.9677]}\end{array}$ & {$[.000745$} & $\begin{array}{l}.000272 \\
{[.3174]}\end{array}$ \\
\hline YRSSCHSQ & $\begin{array}{l}0.000693 \\
{[6.585]}\end{array}$ & $\begin{array}{r}0.0058 \\
{[2.375]}\end{array}$ & {$[6.0047$} & $\cdots$ & -- & {$[1.9582]$} & -- & -- \\
\hline \multicolumn{9}{|l|}{ Income } \\
\hline FAMINC & $\begin{array}{l}-0.00986 \\
{[3.864]}\end{array}$ & $\begin{array}{c}0.220 \\
{[2.965]}\end{array}$ & {$[6.757]$} & {$\left[\begin{array}{c}.122 \\
{[5.835]}\end{array}\right.$} & {$[2.0241$} & $\begin{array}{l}-.001127 \\
{[.2731]}\end{array}$ & {$[2.01163$} & {$\left[\begin{array}{c}-.07138 \\
{[10.109]}\end{array}\right.$} \\
\hline $\begin{array}{l}\text { FAMINCSQ } \\
\text { Last Worked }\end{array}$ & -- & -- & $\begin{array}{l}-.0617 \\
{[3.46]}\end{array}$ & $\begin{array}{r}-.0716 \\
{[3.192]}\end{array}$ & $\begin{array}{r}-.0042 \\
{[1.702]}\end{array}$ & -. & -- & {$\left[\begin{array}{r}.00979 \\
{[7.3406]}\end{array}\right.$} \\
\hline BEFORB 1970 & $\begin{array}{r}-0.0813 \\
{[21.645]}\end{array}$ & $\begin{array}{l}-0.213 \\
{[3.197]}\end{array}$ & {$\left[\begin{array}{r}-.3228 \\
{[14.366]}\end{array}\right.$} & $\begin{array}{r}-.1884 \\
{[15.313]}\end{array}$ & {$\left[\begin{array}{r}-.06977 \\
{[10.0063]}\end{array}\right.$} & $\begin{array}{r}-.0295 \\
{[4.678]}\end{array}$ & {$[3.02744$} & $\begin{array}{r}-.01094 \\
{[1.9544]}\end{array}$ \\
\hline NEVER & $\begin{array}{r}-0.0830 \\
{[16.626]}\end{array}$ & $\begin{array}{l}-0.136 \\
{[2.454]}\end{array}$ & $\begin{array}{r}-.2792 \\
{[7.517]}\end{array}$ & $\begin{array}{r}-.1308 \\
{[6.415]}\end{array}$ & $\begin{array}{r}-.0852 \\
{[6.889]}\end{array}$ & $\begin{array}{r}-.03858 \\
{[4.0505]}\end{array}$ & $\begin{array}{r}-.0376 \\
{[3.338]}\end{array}$ & {$\left[\begin{array}{l}-.03912 \\
{[5.968]}\end{array}\right.$} \\
\hline \multicolumn{9}{|l|}{ Region } \\
\hline ATL & $\begin{array}{l}-0.0152 \\
{[2.382]}\end{array}$ & $\begin{array}{l}-0.127 \\
{[1.626]}\end{array}$ & $\begin{array}{r}-.0374 \\
{[1.176]}\end{array}$ & $\begin{array}{r}-.0252 \\
{[1.239]}\end{array}$ & $\begin{array}{r}.00320 \\
{[.2530]}\end{array}$ & {$[.00362$} & {$[.001575$} & {$[2.02457$} \\
\hline QUE & $\begin{array}{r}0.0072 \\
{[1.217]}\end{array}$ & $\begin{array}{l}-0.0037 \\
{[0.038]}\end{array}$ & $\begin{array}{l}-.0086 \\
{[.2674]}\end{array}$ & $\begin{array}{r}.0637 \\
{[3.389]}\end{array}$ & -.01138 & {$\left[\begin{array}{l}.00860 \\
{[.8378]}\end{array}\right.$} & {$[.01218$} & $\begin{array}{r}.004016 \\
{[.46069]}\end{array}$ \\
\hline PR & $\begin{array}{r}-0.0255 \\
{[5.187]}\end{array}$ & $\begin{array}{l}-0.042 \\
{[0.679]}\end{array}$ & $\begin{array}{r}-.0508 \\
{[2.070]}\end{array}$ & {$[.000346$} & $\begin{array}{r}-.0191 \\
{[1.947]}\end{array}$ & $\begin{array}{r}-.0258 \\
{[2.639]}\end{array}$ & $\begin{array}{r}-.01454 \\
{[1.2800]}\end{array}$ & $\begin{array}{r}-.02960 \\
{[4.0683]}\end{array}$ \\
\hline BC & $\begin{array}{r}0.0051 \\
{[0.937]}\end{array}$ & $\begin{array}{l}-0.041 \\
{[0.580]}\end{array}$ & $\begin{array}{l}-.0084 \\
{[.2920]}\end{array}$ & $\begin{array}{r}.02999 \\
{[1.7206]}\end{array}$ & {$[.00662$} & $\begin{array}{l}.006947 \\
{[.7197]}\end{array}$ & $\begin{array}{l}-.003050 \\
{[.2474]}\end{array}$ & $\begin{array}{l}-.004315 \\
{[.5562]}\end{array}$ \\
\hline \multicolumn{9}{|l|}{ Ur ban/Rural } \\
\hline TOWN & $\begin{array}{l}-0.0227 \\
{[5.340]}\end{array}$ & $\begin{array}{c}0.021 \\
{[0.390]}\end{array}$ & $\begin{array}{r}-.0609 \\
{[2.878]}\end{array}$ & $\begin{array}{r}-.0569 \\
{[4.187]}\end{array}$ & {$\left[\begin{array}{l}-.01445 \\
{[1.661]}\end{array}\right.$} & {$\left[\begin{array}{l}-.009927 \\
{[1.283]}\end{array}\right.$} & {$\left[\begin{array}{l}-.01407 \\
{[1.428]}\end{array}\right.$} & $\begin{array}{r}-.0129 \\
{[2.071]}\end{array}$ \\
\hline RNF & $\begin{array}{r}-0.0196 \\
{[4.154]}\end{array}$ & $\begin{array}{r}-0.0065 \\
{[0.110]}\end{array}$ & $\begin{array}{r}-.06119 \\
{[2.4687]}\end{array}$ & $\begin{array}{r}-.0358 \\
{[2.361]}\end{array}$ & $\begin{array}{r}.00887 \\
{[.9983]}\end{array}$ & $\begin{array}{r}.00232 \\
{[.2700]}\end{array}$ & -.00815 & {$\left[\begin{array}{l}-.02020 \\
{[2.970]}\end{array}\right.$} \\
\hline FARM & $\begin{array}{l}-0.0560 \\
{[7.211]}\end{array}$ & $\begin{array}{c}0.127 \\
{[1.015]}\end{array}$ & $\begin{array}{l}-.0078 \\
{[.1538]}\end{array}$ & $\begin{array}{r}-.01947 \\
{[.7184]}\end{array}$ & $\begin{array}{r}-.0262 \\
{[1.626]}\end{array}$ & $\begin{array}{r}-.00970 \\
{[.7063]}\end{array}$ & $\begin{array}{r}-.0339 \\
{[2.160]}\end{array}$ & {$\left[\begin{array}{c}-.06915 \\
{[6.493]}\end{array}\right.$} \\
\hline
\end{tabular}


TABLE 1 (cont'd.)

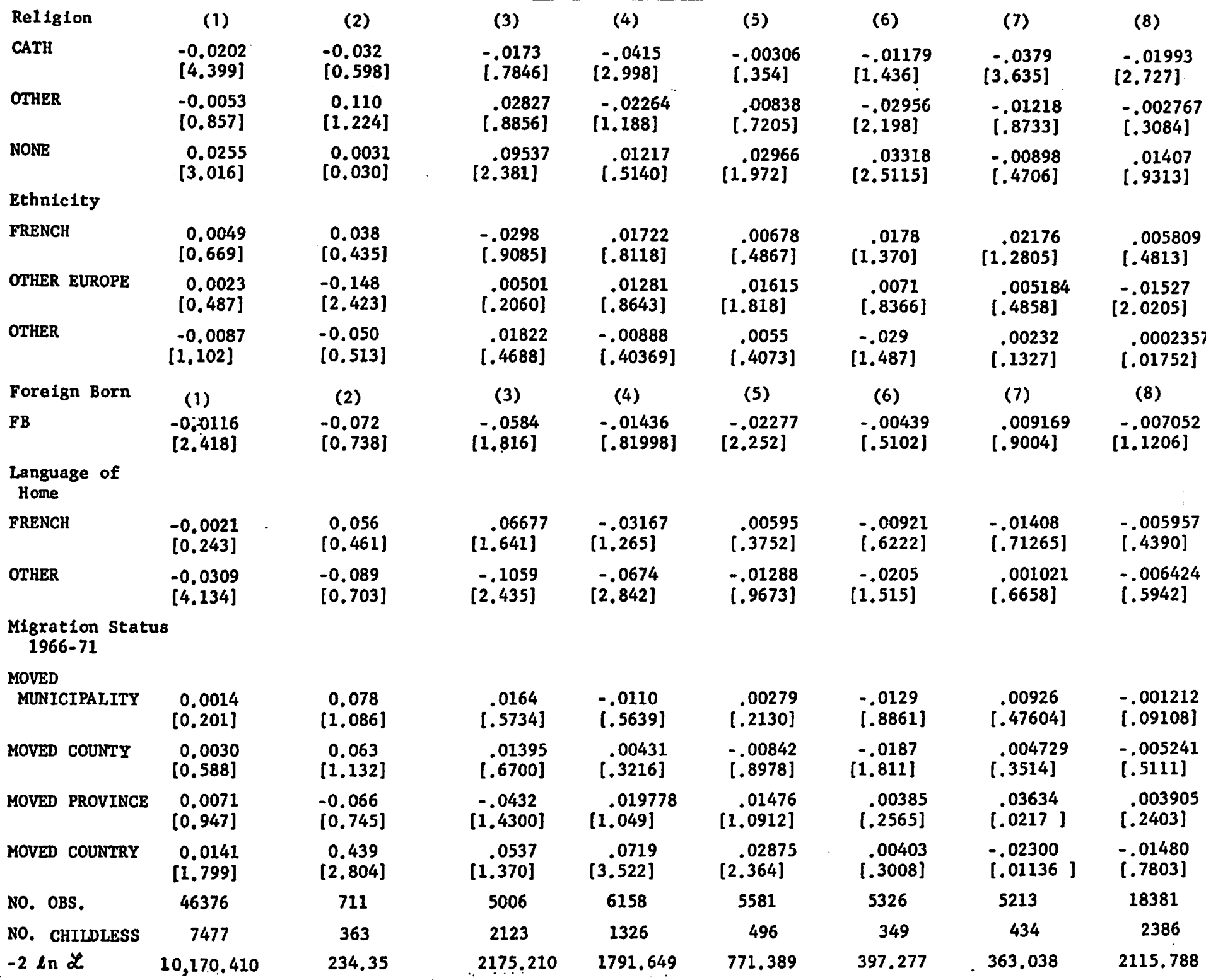

Notes: 1. The dependent variable is coded 1 if the number of children ever born equaled zero, and 0 otherwise.

2. The reported coefficients are the marginal effects of independent variables on the probability of being childiess, evaluated at the mean.

3. Absolute value of asymptotic t-statistic reported in parentheses beneath each coefficient. critical values for $5 \%$ and $10 \%$ confidence levels are 1.960 and 1.645 , respectively.

4. All regressions included a constant term, coefficient not reported.

5. The reference categories are: worked in 1970 and/or 1971, resident in large urban area in Ontario; Religion: Protestant; Ethnicity: British; native born; language of home: English; did not move 1966-71.

6. (-2) $\ln \mathcal{X}$ is minus 2 times the $\log$ likelihood ratio, distributed $\chi^{2}$ with $k-1$ degrees of freedom, where $k$ is the number of regressors. 
positive coefficients indicate that, holding marriage duration and other factors constant, older women--that is, women who married later--are more likely to be childless. A fifth order polynomial in marriage duration was introduced, with each of the terms being statistically significant. Our results confirm those of $G, B$ \& $E$ that marriage duration is an important determinant of childlessness. The coefficients on the polynomial terms in marriage duration alternate in sign, indicating a highly non-linear relationship.

Figure 1 depicts the predicted probability of being childless by marriage duration implied by the regression in column (1), for women married at age 22. 6 , the mean age of marriage, and having the sample mean values of all other characteristics. At zero marriage duration $72 \%$ of women are predicted to be childless. The schedule falls rapidly so that by seven years of marriage only $10 \%$ of women are predicted to be childless. The curve reaches a minimum of $5.5 \%$ childlessness--close to levels of "involuntary childlessness" (Veevers, 1972)-by 13-15 years of marriage and thereafter rises slowly. The increasing incidence of childlessness at higher marriage durations reflects the use of cross-section rather than longitudinal data. Without panel data it is not possible to distinguish time series and longitudinal changes. The study of Poston and Gotard (1977) for the U.S. suggests that the increasing incidence of childlessness at high marriage durations observed in Figure 1 reflects the lower incidence of childlessness among women whose prime years of childbearing coincided with the post-war baby boom.

Turning to achieved and ascribed characteristics we find that our alternative empirical strategy yields results which contrast with those of Grindstaff et al. Both schooling and its square enter with statistically significant 


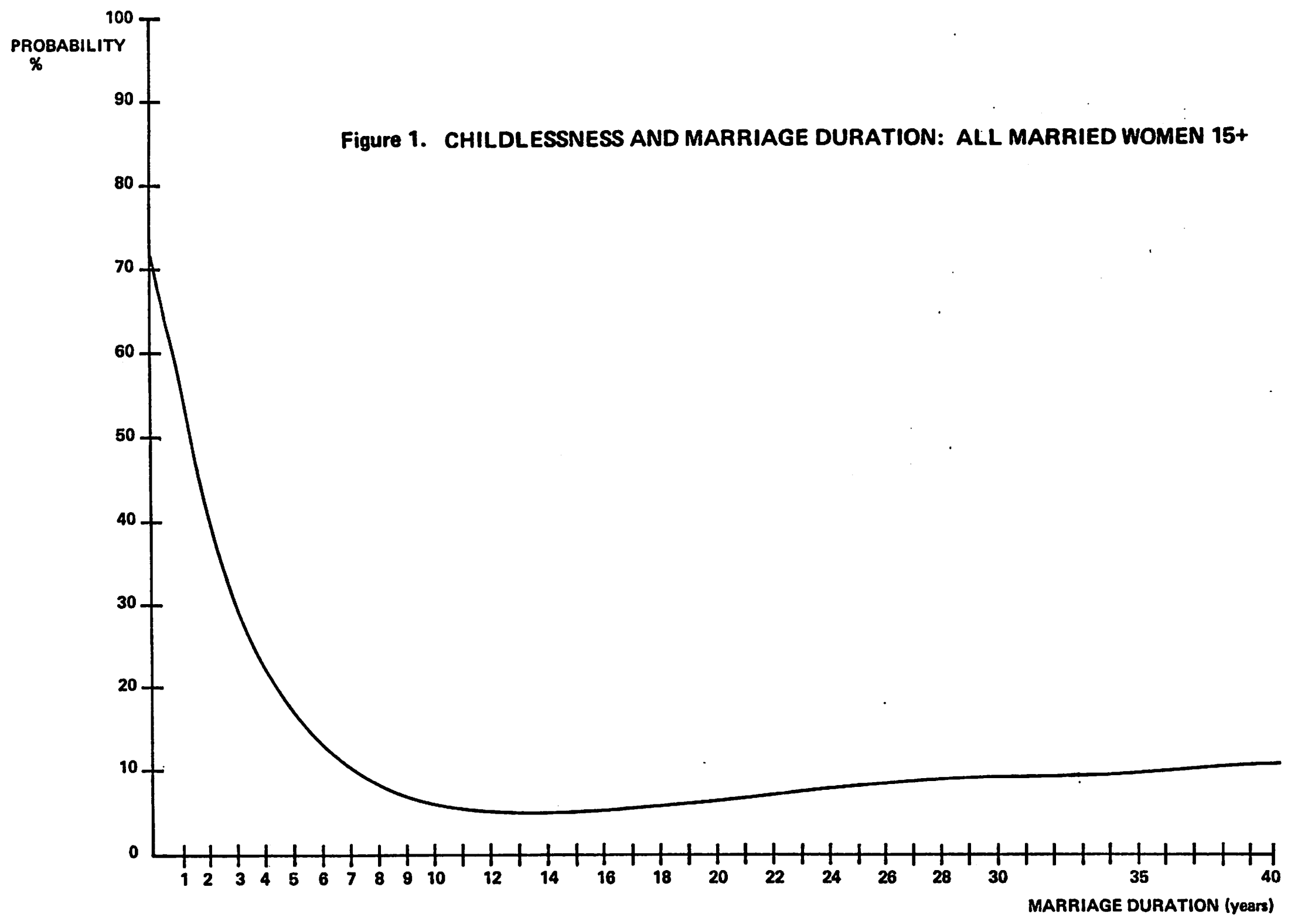


coefficients which have opposite signs, their relative magnitudes indicating a U-shaped relationship between childlessness and educational attainment. Women with close to 8 years of schooling are predicted to have the lowest incidence of childlessness and levels of schooling above and below this level are associated with higher rates of childlessness. At the mean level of schooling an additional year of schooling has a small positive impact on the probability of childlessness. This finding of a U-shaped relationship between education and childlessness contrasts with the results of $G$, $B$ \& $E$, who in their multivariate analysis of the whole sample find no statistically significant relationship between these two variables. The coefficient on family income is negative and statistically significant indicating that, close to the mean level of income, an extra $\$ 1,000$ in family income brings about a small reduction in childlessness. The inverse relationship between childlessness and family income is consistent with the results reported by Wolowyra (1977) using a more restricted set of control variables. Neither of these two results--the U-shaped relation between childlessness and education and the inverse relationship between income and childlessness--were found by G, B $\mathrm{E}$, possibly because in their study these variables are coded into relatively few categories.

Like $G, B$ E we find that labour force status and childlessness are correlated. Both categories of women who did not participate in the labour force in 1970 and/or 1971 had a significantly lower probability of being childless in 1971, in the order of 8 percentage points. We note however that, since women's labour force status is subject to individual choice, these estimates of the influence of labour force participation on childlessness are potentially biased. We shall return to this point later. There is some evidence of regional variations in the incidence of childlessness. Women in the 
Maritimes and Prairie provinces have $1.5 \%$ and $2.6 \% 10$ wer probabilities (respectively) of being without children compared to women in Ontario. The remaining provinces, Quebec and B.C. do not differ significantly from Ontario, the reference category. Urban/rural locations exhibit significant differences. Women in small urban areas (TOWN) and those with rural non-farm residences have approximately $2 \%$ lower probabilities of having zero children compared to women in large urban areas. The difference between farm women and those dwelling in larger urban areas is more substantial, with farm women having a $5.6 \%$ lower probability of having no children. The differences between farm women and women located in rural non-farm or small urban areas (TOWN) are also statistically significant. These observations regarding urban/rural differences in the incidence of childlessness are consistent with the hypothesis that the costs of raising children are successively higher as the size of place increases and that the greater employment opportunities of farm children imply higher pecuniary returns to children for farm families in comparison to urban families where the returns to children are largely non-pecuniary (e.g., see Rosenzweig, 1977)

A number of ascribed (background) characteristics are found to be correlated with childlessness, holding other variables constant. Catholic women have a $2 \%$ lower probability, and women with no religious affiliation a $2.6 \%$ higher probability of being without children, compared to the Protestant reference group. The finding of a significant Catholic-Protestant differential in childlessness contrasts with the conclusions of Grindstaff et al (1981, p.341) and suggests that the characteristic Catholic fertility pattern had not disappeared altogether in Canada by 1971 .

Finally, amongst the migration status variables, only the international migration variable attains significance at the $10 \%$ level, indicating that recent international migrants have a $1.4 \%$ higher probability of being childless compared to women who have not moved. This may reflect the lower costs of migration for 
women with smaller completed families or delayed childbearing by international migrants.

The fact that our empirical results yield a number of statistically significant coefficients allows us to list a number of characteristics associated with childlessness. In Canada as of 1971 a childless woman was likely to possess a number of the following characteristics: a native-born older woman; married relatively few years; with an educational attainment markedly different from the average (either high or low); with a low family income; currently working; residing outside the Maritime and Prairie provinces in a large urban area; and with no religious affiliation. This statistical 'portrait' of childlessness differs from Veevers' (1979) portrayal of voluntary childlessness in that it includes low education and low-income families. This characterization also contrasts sharply with the conclusions of Grindstaff et al that "differentials in childlessness are no longer readily observable among married women living in Canada in the 1970's" (p. 350), and "among older women,...no cluster of achieved variable is particularly important in a portrait of the childless, ever-married woman"(p. 347). We conclude that for a given marriage duration, childless women are not randomly distributed with respect to the ascribed and achieved characteristics listed above.

Having analyzed the results for the whole sample let us turn briefly to examine the correlates of childlessness for the various age groups reported in columns (2) - (8). Even within a number of narrowly defined age groups we find that, holding other factors constant, the incidence of childlessness varies with age. When significant the coefficients indicate that, holding marriage duration and other characteristics constant, women who married later are more likely to have zero children. For all the subsamples marriage duration and its square enter significantly, with coefficients that imply, when evaluated at the mean duration, a diminishing probability of childlessness as duration increases. For the youngest age group, all of whom have been married less than five years, marriage duration is especially important. Figure 2 


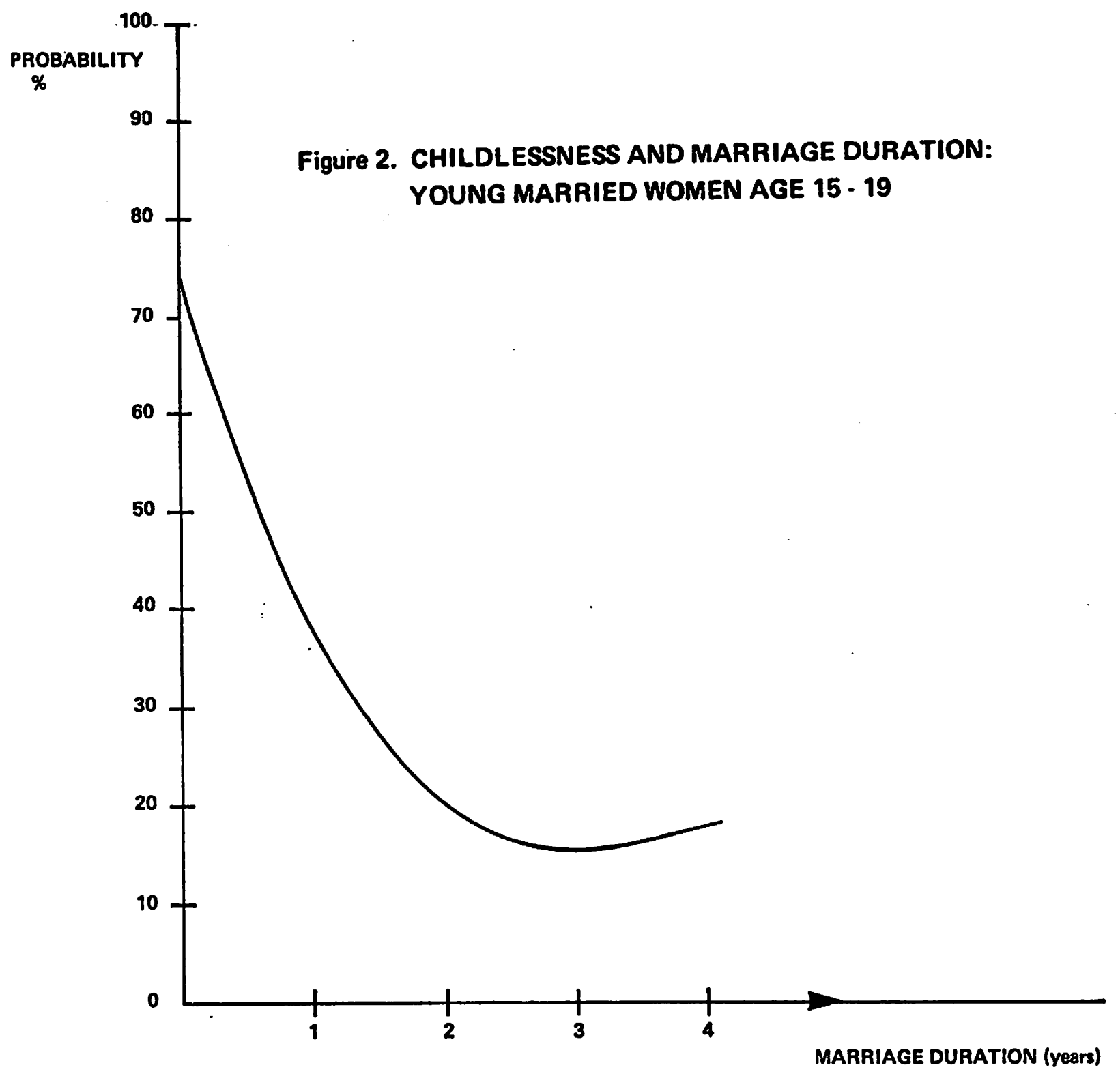


graphs the predicted probability of childlessness by marriage duration for women married at age $171 / 2$, holding constant the remaining characteristics at their mean values for this subsample. At zero marriage duration, $74 \%$ of women are predicted to be childless. Within nine months of marriage this percentage falls to $46 \%$,implying that over $50 \%$ of women aged $17-18$ who married in 1970-71 had a child or were pregnant at the time of marriage. 8 The probability of being childless diminishes rapidly so that after two years of marriage less than $20 \%$ of these women are predicted to be childless. This rate of reduction in childlessness is more rapid than depicted in Figure 1 , which again suggests that the childlessness-marriage duration relationship has varied across cohorts. Looking across successively older cohorts in Table 1, the effect of an additional year of marriage diminishes.

The educational attainment variables are significant for three age cohorts--the two youngest categories and women age 35-39. G, B \& E also find education significant for younger women (15-24); however, the nature of the relationship implied by our empirical results is different. Whereas $G, B$ E find a monotonic positive relationship between childlessness and education among younger women--a finding which appears to be standard in the literature (Veevers 1980)--our results imply for these age groups, as with the sample as a whole, a U-shaped relationship with a minimum at approximately 8 years of schooling, a year or so below the mean schooling for these women. One possible explanation of the divergence between our results and those of Grindstaff et al is that since these researchers only examine a four-category education variable they are unable to detect any variation among women with less than 9 years of schooling. In the remaining age groups 25-34 and $40+$ neither schooling nor its square are significant. 
The family income variable is significant for all but one of the age categories (35-39). An examination of the coefficients reveals the complexity of the interaction between income and childlessness. There is no single relationship between these two variables that characterizes all age groups. For some age categories (15-19, $40-44)$ the probit function is 1inear, while for others (20-34 and 45+) it is non-linear. Thus the overall inverse relationship between family income and childlessness displayed in column (1) appears to be dominated by the older age groups (40+) who comprise over $50 \%$ of the sample. The inverse relationship between family income and childlessness which characterizes the whole sample masks the complex interaction between these two variables exhibited by different cohorts, including a positive relationship among younger women. One possible explanation, suggested by both economists and demographers is that childlessness responds differently to wife's earnings and husband's earnings and the composition of family income varies over the life cycle producing a complex relationship between family income and childlessness. We examine this possibility in more detail below. The remaining variables may be briefly discussed. Locational variables are important for a number of cohorts--women residing in the Prairie provinces are more likely to have children than women in Ontario. For the oldest age category both Maritime and Prairie residence are associated with a lower incidence of childlessness. Women in their $20^{\prime} \mathrm{s}$ and $45+$ residing in small urban or rural non-farm locations are less likely to be childless than their contemporaries in large urban areas. Farm residence is only significant for older women. Religious differences exist amongst women in most age categories. For three age groups having no religious affiliation is associated with childlessness--a result consistent with the findings of other researchers (Veevers, 1980). In three other age categories, including older women (40+), Catholics are less likely to childless than Protestants. 
There is very little variation in childlessness across ethnic groups, once other characteristics are held constant. The only significant differences are among the youngest and oldest categories, where women with an "OTHER EUROPE" origin are less likely to be childless than women of British origin. Neither for ethnicity nor language (mother tongue or home language) do we find any significant French-English differential. Women in their 20's with a home language other than the two official languages are less likely to be childless than English language women. Lastly, among women $<35$ either foreign birth or recent international migration is associated with childlessness. 9

The results of this multivariate probit analysis of childlessness can be summarized by saying that, in addition to marriage duration, we find that both achieved and ascribed characteristics are significant predictors of childlessness. For all age groups education and/or family income are significant determinants of zero parity. Furthermore, location and religious differences in the incidence of childlessness exist amongst all except the youngest (teenage) women.

IV. An Alternative Model of Childlessness

We turn now to re-examine the empirical model of childlessness estimated by Carliner et al (1980). The issue to be examined is whether the results of that study are sensitive to the introduction of marriage duration--the demographic variable which turns out to be important in the work of G, B \& E. Following Carliner et al we drop the labour force status and migration variables from the list of independent variables since these decisions, like choices regarding fertility, are endogenous. We also drop the ethric dummy variables since these characteristics are not considered in the Carliner et al study. On the basis of an economic model of lifetime fertility and labour supply these authors show that fertility should depend on the lifetime wage 
rates of husband and wife, the non-labour income of the family (i.e., income excluding earnings), and prices. Here we follow Carliner et al by using the wife's education as a measure of her potential earning ability in the labour market. Under the conventional assumption made by economists that children are "female time-intensive", wife's education is expected to be positively related to childlessness (e.g., see Carliner et al, 1980). We note, however, that economists (e.g., Michae1, 1973) and other social scientists have recognized that education may influence childlessness through its effect on contraceptive knowledge and other channels in addition to effects via potential labour market earnings. The fact that earnings information is only available for women who worked in 1970 precludes the use of wife's earnings at this stage in the analysis. The family income variable is dropped, instead we introduce two variables: the husband's schooling and total family income less the earnings of the wife ("other income") as a set of proxies for the husband's wage and family non-labour income. 0ther interpretations of these variables are clearly possible. Since differences across men in wage rates are likely to be associated with variations in both schooling and other income we are not able to identify the separate influences of variations in the husband's wage and non-labour income. Nevertheless, husband 's education and other income represent potentially important determinants of childlessness. The remaining location, language and religion variables can be interpreted as capturing variations across families in wages, prices or 'tastes' for children. In addition we control for the demographic variables : the duration of marriage and age.

Table 2 reports the results of these probit regressions. The sample sizes are somewhat smaller than in Table 1 since the sample was restricted to 
TABLE 2: An Alternative Model of Childlessness: Probit Regressions

Reg Nn.:

Sample

Ind ependent

Variables/

AGE

AGESQ

Marriage

Duration

MD

MDSQ

$\mathrm{MD}^{3}$

$\mathrm{MD}^{4}$

$\mathrm{MD}^{5}$

Education

of wife

IRSSCH

YRSSCHSQ

Educat ion

of Husband

YRSSCH

YRSSCHSQ

Other Income

INCOME

INCOMESQ

Region

ATL

QUE

PR

BC
(1)

A11 Ages
(2)

(3)

Age $15-19$
(4)

(5)

$20-24$
(6)

$25-29 \quad 30-34$
(7)

$35-39$
(9)

$45+$

$\begin{array}{ccc}-0.0230 & 0.0076 & 0.0705 \\ {[37.044]} & {[7.071]} & {[2.617]} \\ 0.000236 & 0.000051 & \cdots \\ {[35.097]} & {[4.576]} & \end{array}$

$-$

--

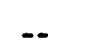

$-$

$$
\begin{array}{r}
0.0313 \\
{[4.528]}
\end{array}
$$$$
\begin{array}{r}
0.0057 \\
-\quad \quad[2.300]
\end{array}
$$$$
\begin{array}{r}
0.0071 \\
{[3.356]}
\end{array}
$$$$
\begin{array}{r}
0.0007 \\
{[0.275]}
\end{array}
$$

0.0263

[2.

--

--

[8.583]

$-0.000115$

[4.423]

$$
\begin{gathered}
-0.1008 \\
{[42.343]} \\
0.00689 \\
{[25.686]} \\
-0.000235 \\
{[18.768]} \\
0.363 \times 10^{-5} \\
{[14.621]} \\
-0.209 \times 10^{-7} \\
{[11.964]}
\end{gathered}
$$$$
-0.481
$$$$
\text { [6.702] }
$$$$
0.0648
$$$$
\text { [2.273] }
$$

$\begin{array}{ccc}-0.2361 & -0.1121 & -0.0540 \\ {[16.122]} & {[17.310]} & {[7.041]} \\ 0.0132 & 0.0053 & 0.0034 \\ {[5.614]} & {[9.520]} & {[3.508]} \\ \ldots & -- & -0.000083 \\ \ldots & & {[2.240]} \\ \ldots & -- & -. \\ & & \end{array}$

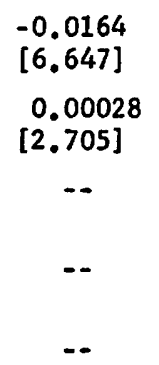

-0.0164
$[6.647]$

$-0.0252$

[9.038]

$-0.0144$

0.00051

[5.676]

[13.923]

0.000033

[18.783]

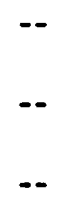

$-0.0070$

$-0.0080$

$-0.139$

[2.108]

$-0.317$

[1. 836]

0.0082
$[3.527]$

0.0031
$[2.161]$

[2.216]

[3.470]

-.

-.

[5.529]

0.0033

0.0115

0.0188

0.0059

[5.216]

[2.960]

0.0103

1.067

$-0.1181$

[20.656]

0.0147

[12.619]

$-0.0796$

[14.522]

0.137

[1.520]

0.0099

[8.870]

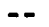

$-\cdot$

$-0.0232$

[3.590]

-0.119
$[1.259]$

0.0025

[0.420]

$-0.0299$

[0.285]

$-0.0271$

$-0.0323$

[5.565]

$-0.0968$

[1.495]

$-0.024$

$[0.330]$

[0.283]

[0.298]

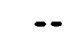

-0.0384
$[1.482]$
.-

$-$

$-0.0900$

[2.712]

$-0.0138$

[0.424]

$-0.0804$

[3.334]

$-0.0096$

[0.337]
$-0.0075$

[0.349]

0.0456

[2.320]

$-0.0099$

[0.616]

0.0204

[1.122]
$-0.00038$

[1.773]

-0.0427
$[3.442]$
$\ldots$

[1.544]

$-0.0170$

[1.375]

$-0.0194$

[1.906]

0.0027

[0.233]
$-0.0214$
0.0007

[0.588]

--

[3.271]

0.00386

0.0010

[0.084]

0.0073

[0.695]

$-0.0249$

[2.538]

0.0070

[0.712]
[2.143]
0.000026

[0.182]

$-0.0053$

[2.069]

0.00036

[2.799]

[4.238]

$-0.0885$

[12.147]

0.00643

[2.824]

0.0121

$[8.750]$

$-0.0043$

$[0.303]$

$-0.0235$

0.0064

[0.485]

[2.518]

$-0.0155$

[1.394]

$-0.0010$

[0.086]
0.0024

[0.270]

$-0.0296$

[4.091] $=$

$-0.0045$

[0.582] 
TABLE 2 (cont'd.)

\begin{tabular}{|c|c|c|c|c|c|c|c|c|c|}
\hline Urban/Rural & (1) & (2) & (3) & (4) & (5) & (6) & (7) & (8) & (9) \\
\hline TOWN & $\begin{array}{l}-0.0341 \\
{[7.762]}\end{array}$ & $\begin{array}{r}-0.0244 \\
{[5.742]}\end{array}$ & $\begin{array}{r}0.0075 \\
{[0.130]}\end{array}$ & $\begin{array}{l}-0.0691 \\
{[3.291]}\end{array}$ & $\begin{array}{l}-0.0625 \\
{[4.449]}\end{array}$ & $\begin{array}{l}-0.0159 \\
{[1.723]}\end{array}$ & $\begin{array}{r}-0.0131 \\
{[1.653]}\end{array}$ & $\begin{array}{l}-0.0147 \\
{[1.516]}\end{array}$ & $\begin{array}{l}-0.0139 \\
{[2.218]}\end{array}$ \\
\hline $\mathbf{R N F}$ & $\begin{array}{r}-0.0489 \\
{[9.899]}\end{array}$ & $\begin{array}{l}-0.0283 \\
{[5.960]}\end{array}$ & $\begin{array}{r}0.0201 \\
{[0.302]}\end{array}$ & $\begin{array}{r}-0.1007 \\
{[4.089]}\end{array}$ & $\begin{array}{l}-0.0675 \\
{[4.245]}\end{array}$ & $\begin{array}{r}0.0023 \\
{[0.246]}\end{array}$ & $\begin{array}{l}-0.0058 \\
{[0.649]}\end{array}$ & $\begin{array}{l}-0.0147 \\
{[1.342]}\end{array}$ & $\begin{array}{l}-0.0221 \\
{[3.226]}\end{array}$ \\
\hline PARM & $\begin{array}{c}-0.0786 \\
{[9.472]}\end{array}$ & $\begin{array}{l}-0.0604 \\
{[7.584]}\end{array}$ & $\begin{array}{r}0.1760 \\
{[1.237]}\end{array}$ & $\begin{array}{l}-0.0539 \\
{[1.006]}\end{array}$ & $\begin{array}{l}-0.0352 \\
{[1.218]}\end{array}$ & $\begin{array}{l}-0.0414 \\
{[2.306]}\end{array}$ & $\begin{array}{r}-0.0178 \\
{[1.243]}\end{array}$ & $\begin{array}{l}-0.0386 \\
{[2.474]}\end{array}$ & $\begin{array}{l}-0.0698 \\
{[6.470]}\end{array}$ \\
\hline \multicolumn{10}{|l|}{ Religion } \\
\hline CATH & $\begin{array}{r}-0.0095 \\
{[2.065]}\end{array}$ & $\begin{array}{c}-0.0198 \\
{[4.462]}\end{array}$ & $\begin{array}{l}-0.0152 \\
{[0.268]}\end{array}$ & $\begin{array}{l}-0.0152 \\
{[0.705]}\end{array}$ & $\begin{array}{l}-0.0354 \\
{[2.539]}\end{array}$ & $\begin{array}{l}-0.0016 \\
{[0.181]}\end{array}$ & $\begin{array}{r}-0.0082 \\
{[1.037]}\end{array}$ & $\begin{array}{r}-0.0366 \\
{[3.682]}\end{array}$ & $\begin{array}{l}-0.0238 \\
{[3.346]}\end{array}$ \\
\hline OTHER & $\begin{array}{l}-0.0085 \\
{[1.355]}\end{array}$ & $\begin{array}{c}-0.0077 \\
{[1.268]}\end{array}$ & $\begin{array}{r}0.1360 \\
{[1.364]}\end{array}$ & $\begin{array}{l}-0.0021 \\
{[0.0643]}\end{array}$ & $\begin{array}{l}-0.0360 \\
{[1.830]}\end{array}$ & $\begin{array}{r}0.0080 \\
{[0.661]}\end{array}$ & $\begin{array}{r}-0.0292 \\
{[2.183]}\end{array}$ & $\begin{array}{l}-0.0137 \\
{[1.027]}\end{array}$ & $\begin{array}{l}-0.0089 \\
{[1.017]}\end{array}$ \\
\hline NONE & $\begin{array}{r}0.0202 \\
{[2.267]}\end{array}$ & $\begin{array}{r}0.0245 \\
{[2.892]}\end{array}$ & $\begin{array}{r}0.0079 \\
{[0.068]}\end{array}$ & $\begin{array}{r}0.0700 \\
{[1.734]}\end{array}$ & $\begin{array}{r}0.0244 \\
{[0.988]}\end{array}$ & $\begin{array}{r}0.0303 \\
{[1.864]}\end{array}$ & $\begin{array}{r}0.0346 \\
{[2.616]}\end{array}$ & $\begin{array}{l}-0.0081 \\
{[0.430]}\end{array}$ & $\begin{array}{r}0.0023 \\
{[0.149]}\end{array}$ \\
\hline \multicolumn{10}{|l|}{ Foreign Born } \\
\hline $\begin{array}{l}\text { FB } \\
\text { Language of } \\
\text { Home }\end{array}$ & $\begin{array}{l}-0.0124 \\
{[2.634]}\end{array}$ & $\begin{array}{l}-0.0110 \\
{[2.432]}\end{array}$ & $\begin{array}{r}0.0027 \\
{[0.030]}\end{array}$ & $\begin{array}{r}-0.0058 \\
{[2.100]}\end{array}$ & $\begin{array}{r}0.0084 \\
{[0.550]}\end{array}$ & $\begin{array}{r}0.0131 \\
{[1.340]}\end{array}$ & $\begin{array}{c}-0.0054 \\
{[0.655]}\end{array}$ & $\begin{array}{r}0.0037 \\
{[0.385]}\end{array}$ & $\begin{array}{r}-0.0094 \\
{[1.506]}\end{array}$ \\
\hline FRENCH & $\begin{array}{l}-0.00008 \\
{[0.012]}\end{array}$ & $\begin{array}{c}-0.0047 \\
{[0.698]}\end{array}$ & $\begin{array}{r}0.1423 \\
{[1.339]}\end{array}$ & $\begin{array}{l}-0.0047 \\
{[0.134]}\end{array}$ & $\begin{array}{l}-0.0378 \\
{[1.771]}\end{array}$ & $\begin{array}{r}0.0006 \\
{[0.043]}\end{array}$ & $\begin{array}{c}-0.0023 \\
{[0.195]}\end{array}$ & $\begin{array}{c}-0.0036 \\
{[0.233]}\end{array}$ & $\begin{array}{l}-0.0010 \\
{[0.091]}\end{array}$ \\
\hline OTHER & $\begin{array}{r}-0.0260 \\
{[3.398]}\end{array}$ & $\begin{array}{l}-0.0293 \\
{[3.988]}\end{array}$ & $\begin{array}{l}-0.0769 \\
{[0.575]}\end{array}$ & $\begin{array}{l}-0.0839 \\
{[1.852]}\end{array}$ & $\begin{array}{l}-0.0593 \\
{[2.407]}\end{array}$ & $\begin{array}{r}-0.0161 \\
{[1.126]}\end{array}$ & $\begin{array}{l}-0.0238 \\
{[1.798]}\end{array}$ & $\begin{array}{l}-0.0033 \\
{[0.222]}\end{array}$ & $\begin{array}{c}-0.0146 \\
{[1.421]}\end{array}$ \\
\hline No. OBS & 44572 & 44572 & 564 & 4606 & 5904 & 5449 & 5237 & 5133 & 17678 \\
\hline NO. CHILDLESS & 6989 & 6989 & 289 & 1946 & 1247 & 466 & 336 & 416 & 2289 \\
\hline$-2 \ln \alpha$ & 3960.367 & 9228.194 & 159.147 & 1651.444 & 1316.839 & 580.460 & 346.354 & 343.165 & 2071.172 \\
\hline
\end{tabular}

Notes: See Table 1. 
wives of the family head in order to obtain a measure of husband's schooling. In order to examine the impact of the marriage duration variables, columns (1) and (2) present the results of probit regressions which alternately include and exclude the marriage duration variables. When included, the five polynomial terms in marriage duration are highly significant, as evidenced by their substantial t-statistics and the large increment in the log-likelihood ratio. The introduction of the marriage duration variables reduces the coefficient on husband's schooling by about half, reduces the magnitude of location differentials and, as might be expected, reduces the age coefficients. The magnitude of the Catholic-Protestant differentia1, however, doubles. The most interesting result of this comparison is that controlling for marriage duration eliminates any significant Quebec-Ontario difference in probability of childlessness. Thus the $1.6 \%$ higher probability of childlessness in Quebec versus Ontario exhibited in column (1) appears to be attributable to the lower durations of marriage in that province, corresponding to higher ages of marriage. This suggests that an adequate explanation of QuebecOntario fertility differentials and trends should place a high emphasis on the nuptuality patterns exhibited by these provinces.

The main results of interest in Table 2 concern the education and income variables. When husband's schooling, other income, marriage duration, and the remaining characteristics are held constant in the whole sample (column (2)), the relationship between the wife's schooling and the probability of childlessness is U-shaped with the lowest probability at approximately $61 / 2$ years of schooling. At the mean an additional year of schooling increases the probability of childlessness by a small amount. This overall pattern masks considerable diversity across cohorts: for the younger age groups (15-24), 
the relationship is U-shaped with most individuals in the negatively inclined segment; for the middle groups (24-34), the relationship is positive; while for the oldest cohorts (40+), the incidence of childlessness is independent of education. For the older age groups (35+) there is very little evidence of the positive relationship between education and childlessness reported by Carliner et al. However, a relationship of this type does seem to characterize women aged 25-34. These results offer little support for simple versions of the "female time-intensity" hypothesis which is a major component of economic models of fertility behavior.

In the sample as a whole, the relationship between husband's schooling and the absence of children is positive. This positive relationship is observed for families with women in their 20's, and to a first approximation, the 30-34 cohort. However, for families with older women (45+) the relationship is U-shaped, with most families in the negatively inclined segment.

The coefficients on other income are significantly different from zero for all except the youngest cohorts $(15-24)$. For the older cohorts the relationship is U-shaped, however, most families are in the range where income and childlessness are inversely related. The income-childlessness relationship in the present table is less complex than in Table 1, suggesting that one reason for the complexity is the differing relative importance across cohorts of female earnings in total family income. When income is measured excluding the wife's earnings the prevailing relationship between income and childlessness is negative, implying, in the terminology of economics, that for most families, the first child is a 'normal' (or 'superior') commodity.

The remaining results duplicate fairly closely those discussed previously in connection with Table 1 , and therefore require little discussion. We note, however, that contrary to Carliner et al there is virtually no evidence of a French-English differential in childlessness. ${ }^{11}$ 
V. WOMEN' S IABOUR FORCE STATUS AND CHILDLESSNESS

Neither of the previous two sections have dealt adequately with the interaction between women's labour force status and childlessness. The regressions in Section II included measures of recent and lifetime labour force participation, the coefficients of which are potentially biased if labour force status is subject to individual choice. The analysis in Section III excludes these variables, thereby ignoring information on the wife's labour force status, and estimates relationships pooling working and non-working women. However, economists (e.g. Willis, 1973; Robinson and Tomes, 1982) and demographers (e.g. Poston, 1974) have suggested that the determinants of fertility differ depending on whether the wife is in or out of the labour force. To investigate this possibility we cannot simply partition the sample according to labour force status since there is a potential problem of self-selection bias. Instead we employ the procedure developed by Heckman (1979) which involves computing a variable--"lambda"--from an auxilliary probit regression defining the selection rule and introducing this additional variable in the childlessness regressions estimated on the partitioned sample. Table 3 presents the results of this exercise.

Columns (1)-(3) divide the sample by the wife's 'lifetime' labour force participation status, that is, according to whether the wife has ever worked in the labour force prior to the survey. Column (1) reports estimates of a probit equation of the selection rule determining the wife's lifetime labour force status. 12 Since this is not our central focus we avoid a detailed discussion but note that virtually all the regressors enter with statistically significant coefficients implying that there are substantial differences across 
TABLE 3: Labour Force Status and Chlldlessness: Probit Regressions

\begin{tabular}{|c|c|c|c|c|c|c|}
\hline Reg No.: & (1) & (2) & (3) & (4) & (5) & (6) \\
\hline $\begin{array}{l}\text { Sample: } \\
\text { Dependent var: }\end{array}$ & $\begin{array}{l}\text { ALL } \\
\text { LTLPP }\end{array}$ & $\begin{array}{l}\text { NEVER WORKED } \\
\text { CHILDLS }\end{array}$ & $\begin{array}{l}\text { EVER WORKED } \\
\text { CHILDLS }\end{array}$ & $\begin{array}{l}\text { EVER WORKED } \\
\text { LFP70 }\end{array}$ & $\begin{array}{l}\text { WORKED } 1970 \\
\text { CHILDLS }\end{array}$ & $\begin{array}{l}\text { EVER WORKED/NOT IN } 1970 \\
\text { CHILDLS }\end{array}$ \\
\hline AGE & $\begin{array}{r}0.0129 \\
{[9.116]}\end{array}$ & $\begin{array}{r}0.0118 \\
{[3.781]}\end{array}$ & $\begin{array}{r}0.0108 \\
{[7.752]}\end{array}$ & $\begin{array}{r}0.0205 \\
{[8.619]}\end{array}$ & $\begin{array}{r}0.0094 \\
{[2.682]}\end{array}$ & $\begin{array}{r}0.0060 \\
{[3.659]}\end{array}$ \\
\hline AGESQ & $\begin{array}{l}-0.000135 \\
{[9.423]}\end{array}$ & $\begin{array}{l}-0.000035 \\
{[1.099]}\end{array}$ & $\begin{array}{l}0.0000268 \\
{[1.787]}\end{array}$ & $\begin{array}{l}-0.000311 \\
{[11.879]}\end{array}$ & $\begin{array}{l}0.0000823 \\
{[1.740]}\end{array}$ & $\begin{array}{l}0.000031 \\
{[1.598]}\end{array}$ \\
\hline $\mathbf{M D}$ & $\begin{array}{l}-0.0261 \\
{[8.464]}\end{array}$ & $\begin{array}{l}-0.0713 \\
{[9.139]}\end{array}$ & $\begin{array}{r}-0.1166 \\
{[39.895]}\end{array}$ & $\begin{array}{r}-0.1377 \\
{[28.223]}\end{array}$ & $\begin{array}{l}-0.1307 \\
{[9.568]}\end{array}$ & $\begin{array}{l}-0.0734 \\
{[8.037]}\end{array}$ \\
\hline MDSQ & $\begin{array}{l}0.00151 \\
{[4.907]}\end{array}$ & $\begin{array}{r}0.0049 \\
{[8.281]}\end{array}$ & $\begin{array}{l}0.00791 \\
{[24.337]}\end{array}$ & $\begin{array}{r}0.0119 \\
{[21.353]}\end{array}$ & $\begin{array}{l}0.00844 \\
{[6.768]}\end{array}$ & $\begin{array}{l}0.00551 \\
{[6.671]}\end{array}$ \\
\hline $\mathbf{M D}^{3}$ & $\begin{array}{l}-0.5006 \times 10^{-4} \\
{[3.843]}\end{array}$ & $\begin{array}{l}-0.000169 \\
{[7.227]}\end{array}$ & $\begin{array}{l}-0.000268 \\
{[17.532]}\end{array}$ & $\begin{array}{l}-0.000399 \\
{[14.978]}\end{array}$ & $\begin{array}{l}-0.000303 \\
{[6.294]}\end{array}$ & $\begin{array}{l}-0.000191 \\
{[6.322]}\end{array}$ \\
\hline $\mathrm{MD}^{4}$ & $\begin{array}{l}0.7642 \times 10^{-6} \\
{[3.186]}\end{array}$ & $\begin{array}{l}0.265 \times 10^{-5} \\
{[6.322]}\end{array}$ & $\begin{array}{l}0.409 \times 10^{-5} \\
{[13.354]}\end{array}$ & $\begin{array}{l}0.571 \times 10^{-5} \\
{[10.450]}\end{array}$ & $\begin{array}{l}0.504 \times 10^{-5} \\
{[5.534]}\end{array}$ & $\begin{array}{l}0.289 \times 10^{-5} \\
{[5.970]}\end{array}$ \\
\hline $\mathrm{MD}^{5}$ & $\begin{array}{l}-0.4127 \times 10^{-8} \\
{[2.600]}\end{array}$ & $\begin{array}{c}-0.154 \times 10^{-7} \\
{[5.643]}\end{array}$ & $\begin{array}{l}-0.231 \times 10^{-7} \\
{[10.584]}\end{array}$ & $\begin{array}{l}-0.296 \times 10^{-7} \\
{[7.387]}\end{array}$ & $\begin{array}{l}-0.313 \times 10^{-7} \\
{[4.593]}\end{array}$ & $\begin{array}{l}-0.160 \times 10^{-7} \\
{[5.591]}\end{array}$ \\
\hline Education of Wife YRSSCH & $\begin{array}{l}0.01108 \\
{[4.158]}\end{array}$ & $\begin{array}{l}-0.0043 \\
{[1.334]}\end{array}$ & $\begin{array}{l}0.01126 \\
{[9.292]}\end{array}$ & $\begin{array}{l}-0.0101 \\
{[2.094]}\end{array}$ & $\begin{array}{r}0.0228 \\
{[3.240]}\end{array}$ & $\begin{array}{l}-0.0102 \\
{[2.704]}\end{array}$ \\
\hline YRSSCHSQ & $\begin{array}{l}0.000544 \\
{[3.648]}\end{array}$ & $\begin{array}{l}0.00063 \\
{[2.339]}\end{array}$ & $-\infty$ & $\begin{array}{c}0.00199 \\
{[8.318]}\end{array}$ & $\begin{array}{l}-0.000753 \\
{[2.353]}\end{array}$ & $\begin{array}{l}0.00060 \\
{[3.245]}\end{array}$ \\
\hline $\begin{array}{l}\text { Education of Husband } \\
\text { YRSSCH }\end{array}$ & $\begin{array}{r}0.0080 \\
{[11.313]}\end{array}$ & $\begin{array}{r}0.0031 \\
{[1.588]}\end{array}$ & $\begin{array}{r}0.0061 \\
{[7.638]}\end{array}$ & $\begin{array}{r}0.0193 \\
{[4.749]}\end{array}$ & $\begin{array}{r}0.0125 \\
{[6.415]}\end{array}$ & $\begin{array}{l}-0.0004 \\
{[0.401]}\end{array}$ \\
\hline YRSSCHSQ & -- & $\cdots$ & $\ldots$ & $\begin{array}{l}-0.00132 \\
{[7.125]}\end{array}$ & -- & -- \\
\hline Other Income INCOME & $\begin{array}{l}-0.0131 \\
{[4.506]}\end{array}$ & $\begin{array}{l}-0.0663 \\
{[7.677]}\end{array}$ & $\begin{array}{r}-0.0813 \\
{[12.335]}\end{array}$ & $\begin{array}{r}-0.1584 \\
{[16.447]}\end{array}$ & $\begin{array}{l}-0.0833 \\
{[3.901]}\end{array}$ & $\begin{array}{r}-0.0575 \\
{[5.413]}\end{array}$ \\
\hline INCOMESQ & -- & $\begin{array}{r}0.0085 \\
{[4.533]}\end{array}$ & $\begin{array}{c}0.00889 \\
{[6.495]}\end{array}$ & $\begin{array}{r}0.0133 \\
{[6.647]}\end{array}$ & $\begin{array}{r}0.0112 \\
{[3.488]}\end{array}$ & $\begin{array}{r}0.0066 \\
{[4.649]}\end{array}$ \\
\hline Wife's Income INCOME & -- & - & -- & -- & $\begin{array}{c}0.552 \\
{[17.801]}\end{array}$ & $\cdots$ \\
\hline INCOMESQ & -- & -- & -- & -- & $\begin{array}{l}-0.2780 \\
{[9.576]}\end{array}$ & 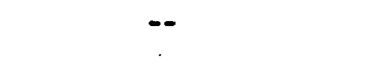 \\
\hline \multicolumn{7}{|l|}{ Region } \\
\hline ATL & $\begin{array}{l}-0.0634 \\
{[9.255]}\end{array}$ & $\begin{array}{l}-0.0553 \\
{[3.224]}\end{array}$ & $\begin{array}{l}-0.0372 \\
{[4.550]}\end{array}$ & $\begin{array}{l}-0.0951 \\
{[8.508]}\end{array}$ & $\begin{array}{l}-0.0319 \\
{[1.838]}\end{array}$ & $\begin{array}{l}-0.0122 \\
{[1.236]}\end{array}$ \\
\hline QUE & $\begin{array}{l}-0.0522 \\
{[8.003]}\end{array}$ & $\begin{array}{l}-0.0310 \\
{[2.110]}\end{array}$ & $\begin{array}{l}-0.0066 \\
{[0.882]}\end{array}$ & $\begin{array}{r}-0.0882 \\
{[8.250]}\end{array}$ & $\begin{array}{r}0.0050 \\
{[0.327]}\end{array}$ & $\begin{array}{l}-0.0021 \\
{[0.225]}\end{array}$ \\
\hline PR & $\begin{array}{l}-0.0164 \\
{[2.874]}\end{array}$ & $\begin{array}{l}-0.0305 \\
{[3.236]}\end{array}$ & $\begin{array}{l}-0.0327 \\
{[5.694]}\end{array}$ & $\begin{array}{r}-0.0269 \\
{[3.304]}\end{array}$ & $\begin{array}{r}-0.0169 \\
{[1.693]}\end{array}$ & $\begin{array}{l}-0.0300 \\
{[4.550]}\end{array}$ \\
\hline BC & $\begin{array}{l}-0.0237 \\
{[3.556]}\end{array}$ & $\begin{array}{l}-0.0317 \\
{[2.662]}\end{array}$ & $\begin{array}{r}0.0030 \\
{[0.469]}\end{array}$ & $\begin{array}{l}-0.0681 \\
{[7.254]}\end{array}$ & $\begin{array}{r}0.0323 \\
{[2.507]}\end{array}$ & $\begin{array}{l}-0.0036 \\
{[0.482]}\end{array}$ \\
\hline Urban/Rura1 Town & $\begin{array}{l}-0.0302 \\
{[6.415]}\end{array}$ & $\begin{array}{l}-0.0193 \\
{[2.125]}\end{array}$ & $\begin{array}{l}-0.0356 \\
{[6.831]}\end{array}$ & $\begin{array}{l}-0.0371 \\
{[5.013]}\end{array}$ & $\begin{array}{l}-0.0472 \\
{[4.949]}\end{array}$ & $\begin{array}{l}-0.0055 \\
{[0.927]}\end{array}$ \\
\hline $\mathbf{R N R}$ & $\begin{array}{r}-0.0631 \\
{[12.624]}\end{array}$ & $\begin{array}{l}-0.0269 \\
{[1.875]}\end{array}$ & $\begin{array}{l}-0.0536 \\
{[8.342]}\end{array}$ & $\begin{array}{r}-0.1103 \\
{[13.078]}\end{array}$ & $\begin{array}{l}-0.0565 \\
{[3.641]}\end{array}$ & $\begin{array}{l}-0.0101 \\
{[1.109]}\end{array}$ \\
\hline FARM & $\begin{array}{l}-0.0297 \\
{[3.938]}\end{array}$ & $\begin{array}{l}-0.0434 \\
{[3.336]}\end{array}$ & $\begin{array}{l}-0.0723 \\
{[7.780]}\end{array}$ & $\begin{array}{r}-0.3019 \\
{[23.472]}\end{array}$ & $\begin{array}{l}-0.0362 \\
{[0.869]}\end{array}$ & $\begin{array}{l}-0.051 \\
{[2.952]}\end{array}$ \\
\hline
\end{tabular}


TABLE 3: (Cont'd.)

\begin{tabular}{|c|c|c|c|c|c|c|}
\hline Religion & (1) & (2) & (3) & (4) & (5) & (6) \\
\hline CATH & $\begin{array}{l}-0.0213 \\
{[4.100]}\end{array}$ & $\begin{array}{r}-0.0244 \\
{[2.734]}\end{array}$ & $\begin{array}{r}-0.0269 \\
{[5.063]}\end{array}$ & $\begin{array}{r}0.0088 \\
{[1.161]}\end{array}$ & $\begin{array}{r}-0.0345 \\
{[3.771]}\end{array}$ & $\begin{array}{r}-0.0187 \\
{[3.176]}\end{array}$ \\
\hline OTHER & $\begin{array}{r}-0.0187 \\
{[2.722]}\end{array}$ & $\begin{array}{l}-0.0155 \\
{[1.418]}\end{array}$ & $\begin{array}{c}-0.0112 \\
{[1.559]}\end{array}$ & $\begin{array}{l}-0.0016 \\
{[0.159]}\end{array}$ & $\begin{array}{c}-0.0081 \\
{[0.663]}\end{array}$ & $\begin{array}{l}-0.0043 \\
{[0.563]}\end{array}$ \\
\hline NONE & $\begin{array}{r}0.0041 \\
{[0.338]}\end{array}$ & $\begin{array}{r}0.0197 \\
{[1.066]}\end{array}$ & $\begin{array}{r}0.0244 \\
{[2.502]}\end{array}$ & $\begin{array}{r}-0.0237 \\
{[1.544]}\end{array}$ & $\begin{array}{r}0.0468 \\
{[2.887]}\end{array}$ & $\begin{array}{r}-0.0047 \\
{[0.395]}\end{array}$ \\
\hline $\begin{array}{l}\text { Foreign Born FB } \\
\text { Language of Home }\end{array}$ & $\begin{array}{r}-0.0176 \\
{[3.293]}\end{array}$ & $\begin{array}{l}-0.0279 \\
{[3.149]}\end{array}$ & $\begin{array}{r}-0.0110 \\
{[2.049]}\end{array}$ & $\begin{array}{r}0.0299 \\
{[3.760]}\end{array}$ & $\begin{array}{r}-0.0175 \\
{[1.738]}\end{array}$ & $\begin{array}{r}0.0003 \\
{[0.049]}\end{array}$ \\
\hline FRENCH & $\begin{array}{r}-0.1189 \\
{[16.488]}\end{array}$ & $\begin{array}{l}-0.0317 \\
{[1.170]}\end{array}$ & $\begin{array}{l}-0.0470 \\
{[4.623]}\end{array}$ & $\begin{array}{r}-0.0129 \\
{[1.064]}\end{array}$ & $\begin{array}{c}-0.0746 \\
{[4.018]}\end{array}$ & $\begin{array}{l}0.0120 \\
{[1.028]}\end{array}$ \\
\hline OTHER & $\begin{array}{l}-0.0511 \\
{[6.805]}\end{array}$ & $\begin{array}{l}-0.0261 \\
{[1.652]}\end{array}$ & $\begin{array}{r}-0.0419 \\
{[4.599]}\end{array}$ & $\begin{array}{r}0.0761 \\
{[5.967]}\end{array}$ & $\begin{array}{l}-0.0782 \\
{[4.263]}\end{array}$ & $\begin{array}{r}-0.0035 \\
{[0.327]}\end{array}$ \\
\hline \multicolumn{7}{|c|}{ Selection Variables } \\
\hline$\lambda_{A L T}$ & -- & $\cdots$ & $\begin{array}{l}-0.2393 \\
{[7.928]}\end{array}$ & $\cdots$ & $\begin{array}{r}-0.4556 \\
{[6.317]}\end{array}$ & $\begin{array}{r}0.0418 \\
{[1.207]}\end{array}$ \\
\hline$\lambda_{\mathrm{BLT}}$ & -- & $\begin{array}{r}-0.1048 \\
{[1.481]}\end{array}$ & -- & -- & -- & -- \\
\hline$\lambda_{\mathrm{A} 70}$ & - & -- & -- & -- & $\begin{array}{r}0.0567 \\
{[0.728]}\end{array}$ & -- \\
\hline$\lambda_{\mathrm{B} 70}$ & -- & -- & $\cdots$ & -- & -- & $\begin{array}{r}-0.0766 \\
{[2.116]}\end{array}$ \\
\hline No. OBS & 44,572 & 8,875 & 35,697 & 35,697 & 17,805 & 17,892 \\
\hline No. of $0^{\prime} \mathrm{s}$ & 8,875 & 8,105 & 29,478 & 17,892 & 13,356 & 16,122 \\
\hline$-2 \ln \mathcal{Z}$ & $7,769.91$ & 961.61 & $8,027.25$ & $5,134.89$ & $6,522.51$ & $1,637.43$ \\
\hline
\end{tabular}

Notes to Table 3:

1. See notes 1-6 of Table 1.

2. The "lambda" variables which correct for sample selection blas are computed as:

$$
\lambda_{A}=\frac{f(\cdot)}{F(\cdot)}, \lambda_{B}=\frac{-f(\cdot)}{1-F(\cdot)}
$$

where $f(\cdot)$ and $F(\cdot)$ are, respectively, the probability density function and the standard normal cumulative distribution function [see, Heckman, 1979 for details]. $\lambda_{A L T}$ and $\lambda_{B L T}$ represent the selection variables conputed from the lifetime participation equation, $\lambda_{A 70}$ and $\lambda_{B 70}$ represent the selection variables computed from the 1970 participation equation (column (4)).

3. Dependent Variables: LTLFP Lifetime Labourforce Participant 1: if ever worked in the labour market, O: otherwise; LFP70 Labourforce Participant in 1970 1: if worked in 1970, 0: otherwise; CHILDLS Childless 1: if zero parity, 0 : otherwise. 
individuals possessing different characteristics. The positive coefficient on wife's schooling (and its square) can be given the economic interpretation that an additional year of schooling increases an individual's productivity in the labour market (and hence potential wage) by more than it raises productivity in the non-market (household) sector. Similarly the positive coefficient on husband's education implies complementarity between the non-market ('Ieisure') time of spouses (see Robinson and Tomes, 1982). Women with a French home language have a substantially lower probability of having ever worked in the labour force.

Columns (2) and (3) report childlessness regressions for the two subsamples--for women who never worked (column (2)) and women who have worked at some time (colum $(3))$. The significance of the selection variable ( $\lambda_{\text {ALT }}$ ) in column (3) indicates the importance of taking into account the endogeneity

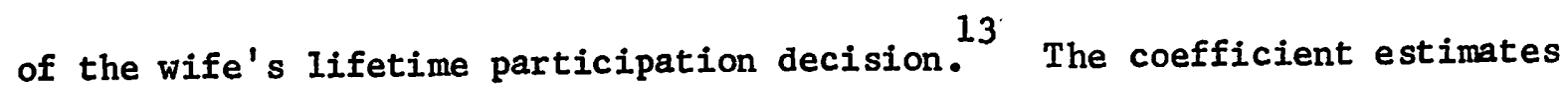
reported in columns (2) and (3) display marked differences. For women who have never worked the relationship between childlessness and female education is U-shaped, reaching a minimum at approximately $31 / 2$ years of schooling. For women who have worked at some point the probability of being childless is a monotonically increasing function of education. At the mean an additional year of schooling increases the probability of childlessness of working women by substantially more than their contempories who have never worked. The effects of husband's schooling also differ across the two groups. For women who have never worked the coefficient on husband's education is insignificantly different from zero, whereas for lifetime labour force participants the coefficient is positive and significant. Among working women those with a French home language have a lower probability of being childless. This result contrasts both with 
the absence of any significant French-English differentials in Tables 1 and 2 and the result reported by Carliner et al that French mother tongue women are more likely to be childless. However these previous results did not control adequately for labour force status, which differs markedly across language groups as column (1) indicates. For both groups of women the relationship between childlessness and income is $U$-shaped with the majority of families on the negatively inclined segment。

Women who have ever worked can be further subdivided into women who are currently working (in 1970) and those who are not currently in the labour force. For current labour force participants the income of the wife can be included as an additional regressor. Again, the estimation should take into account the endogeneity of the current participation decision. Catsiapis and Robinson (1982) have shown that if the two selection criteria are independent then one simply has to compute an additional "lambda" variable for the second selection criterion to be included in the subsequent subsample regressions. Column (4) reports a probit equation of the determinants of current (1970) labour force participation amongst women who have ever worked. The final two columns in Table 3 report childlessness regressions for currently working women and women who have worked in the past but are currently out of the labour force. The fact that one of the two selection variables is significant in each regression implies that it is important to recognize that both lifetime and current labour force status are subject to individual choice, when considering the determinants of childlessness. ${ }^{14}$ of particular interest are the results in column (5) relating the incidence of childlessness to the wife's income for currently working women. Both the quadratic terms in wife's income are highly 
significant, implying a positive relationship between childlessness and wife's income except at high levels of female earnings. At the mean a $\$ 1,000$ increment in wife's earnings raises the probability of childlessness by $37 \%$. In contrast the 'other income' variable, which mainly reflects husband's earnings, has a negative effect on childlessness except at high levels of income. At the mean a $\$ 1,000$ increase in other income reduces the probability of childlessness by $0.6 \%$, an effect which is substantially smaller, in absolute terms, than the impact of wife's income. The se results regarding the differential effects of husband's and wife's income are broadly consistent with models which emphasize the different roles of spouses in bearing and rearing children, a notion captured in the economics literature in terms of the differing 'factor intensities' of children in terms of husband's and wife's time. The fact that variations in the incomes of spouses have differing effects on childlessness offers an explanation for the complex relationship between family income and childlessness observed in this study and by other researchers (e.g. Poston, 1974). Since husband's and wife's income have opposing effects on childlessness, the relationship between family income and childlessness can be expected to differ across groups depending on the fraction of women in the labour force and the variances and covariance of husband's and wife's incomes. Given the contrasting effects of wife's income and other income it is clearly inappropriate to enter these income variables as the sum--family income--since this procedure constrains their effects to be equal, a restriction strongly rejected by the data. The results for women who have worked in the past but are not currently working (column (6)) are broadly similar to those for women who have never worked (colum (2)). The relationship between childlessness and wife's schooling is $\mathrm{U}$-shaped and childlessness is unrelated to husband's education. For 
currently working women (column (5)) the relationship between female education and childlessness is positive, except at high levels (15+ years) where the relationship becomes negative. Also, for two-earner families, a higher level of husband's education increases the probability of zero parity. Among currently working women the French-English differential is market--women with a French home language have a $71 / 2 \%$ lower probability of being childless relative to their English counterparts. These differences underline the importance of distinguishing between families according to the wife's labour force status when analyzing the correlates of child1essness.

VI. CONCLUSIONS

A recent study by Grindstaff et al reported that "differentials in childlessness are no longer readily observable among married women living in the 1970 's" (p. 350). "At ages over 30, the only variable that has an important impact [on childlessness] is marriage duration" (p. 347).

This paper has re-examined the correlates of childlessness in Canada in 1971, using the same data. Iike Grindstaff et al we conclude that marriage duration is an important determinant of childlessness. However our conclusions regarding the importance of ascribed and achieved characteristics differ dramatically. Our empirical results, based on a superior statistical technique, imply that, holding marriage duration constant, childlessness is not a random event distributed independently of measured characteristics. Grindstaff et al concluded that "ascribed characteristics of ever-married women provide no meaningful associations to childlessness" (p. 337). However, based on a multivariate probit analysis we conclude that certain ascribed characteristics are statistically significant predictors of 
the absence of children. For the whole sample and for a number of cohorts, we find that Catholic women are less likely, and women with no religion more likely, to be childless, compared to Protestant women. Moreover, foreign born women are less likely to be childless than the native born, other things equal.

Grindstaff et al also concluded that "factors associated with childlessness are certain achieved variables and they are only significant among the younger age cohorts" (p. 347). However, our results imply that selected achieved characteristics are significant correlates of childlessness, not only for younger cohorts, but also for cohorts over age 30 . In this study women's schooling and/or family income enter as significant determinants of zero parity for all age groups. Moreover, significant differences by labour force status were found for all cohorts, not merely for women still in their child-bearing years.

Location variables are also of some importance, especially for older women $(45+)$. Other things equal, women residing in the Maritimes or Prairie provinces have significantly lower probabilities of being childless, compared to Ontario residents. Urban/rural/farm differentials are statistically significant. For women in their 20 's, and women $45+$, residence in a sma11 urban area of rural non-farm location is associated with a lower probability of being without children compared to residence in a large urban area. For older cohorts $(40+)$ farm residence is associated with a reduced probability of zero children compared to urban or rural non-farm locations. Only for the youngest cohort of teenage women do we find no significant differences in the incidence of childlessness by location. Although in contrast with the conclusions of Grindstaff et al, it is interesting to note that these results 
are, for the most part, consistent with the earlier analysis by the same authors (Balakrishnan et al 1979) of fertility patterns in the 1971 Canadian Census. We also estimated an alternative empirical model based on the work of Carliner et al. In this formulation husband's schooling was introduced as an additional regressor. For the whole sample and for a number of younger cohorts (age $<35$ ), holding other characteristics constant a higher level of husband's education reduces the probability that the couple is childless. For the oldest cohort, however, the converse is true. We also experimented with alternative measures of income. Although the relationship between family income and childlessness is complex, when income is defined excluding the wife's earnings, a more straightforward relationship emerges. With this definition of income, for all cohorts except the youngest (age <24), the prevailing relationship is negative, suggesting that for most families the first child is not an "inferior" commodity.

This paper has done more than merely replicate previous studies. Existing research has not adequately addressed the simultaneity between women's labour force status and childless. In the previous section we examined the determinants of childlessness among working and non-working women, taking into account the endogeneity of labour force status. Marked differences emerge. For working women the prevailing relationship between education and childlessness is positive, while for non-working women it is negative. Husband's education increases the probability of childlessness among working women, but has no effect on non-working women. Among two-earner families, the effects of husband's and wife's income on childlessness are countervailing, wife's income increases, but husband's income decreases the likelihood of a couple being childless. These results imply, firstly, that it is important to distinguish between families according to the wife's labour force status. Secondly, it is 
inappropriate to aggregate the incomes of household members into a single aggregate: family income, a standard procedure in the analysis of childlessness. The results in Table 3 clearly indicate that the effects of an increase in income on childlessness depend critically on the source of income--whether wife's earnings or other income. As a result the overa11 relationship between childlessness and family income is complex. Disaggregating income by source represents a major step in unravelling this complex relationship. Lastly, we note that although there is no evidence of a French-English differential in the whole sample, among working women we find a substantially lower probability of childlessness among francophones. 


\section{Footnotes}

$1_{\text {The urban/rural differences were statistically significant at better }}$ than the $10 \%$ confidence level, the remaining differences at better than the 5\% leve1. In the analysis of Carliner et al the dependent variable is the probability of having any children.

A recent analysis of parity progression among Canadian women aged 35-69 by Kyriazis (1982) also finds that for both Catholic and Protestant women the probability of childlessness depends on the wife's education and husband's projected income, holding age and age at marriage constant.

${ }^{2}$ Carliner et al use the family file, whereas G,B \& $\mathrm{E}$ use the individual file. It is unlikely, however, that this difference alone could account for the divergence in results.

3 The authors of MNA state concerning the "beta" statistic, which is designed to indicate the importance of one independent variable while holding all other independent variables constant, that "we regard the Beta square as an experimental statistic whose precise interpretation is open to further investigation" (Andrews and Messenger, 1973: 13, fn.).

${ }^{4}$ For a detailed description of the construction of these variables see the Appendix.

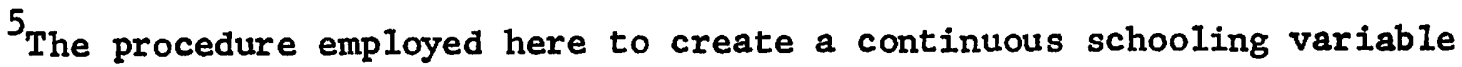
follows closely the assumptions of previous researchers and uses information on regional variations in university entrance requirements and the location of each individual at the completion of high school. See Appendix for details.

6 With marriage duration for the whole sample the polynomial was truncated at the fifth power. Given the inclusion of the first five powers, it is 
exceedingly doubtful that this truncation would bias the estimated coefficients on the other variables. It should also be noted that the significance tests reported here are for each coefficient separately, rather than for groups of variables. In the case of variables with more than two categories (e.g., religion), the t-statistics indicate whether the included categories (Catholic, No Religion, etc.) differ significantly from the omitted reference category (Protestant.).

7 Probit regressions were also estimated using mother tongue rather than home language. The resulting estimates did not differ sufficiently to warrant reporting.

${ }^{8}$ Since both age in 1971 and age at first marriage are coded as integers marriage duration is measured with an error which depends on the distributions of the date of marriage and date of birth. If these two variables are uncorrelated the expected value of the error is zero. However if date of marriage depends on birth date, which would occur for partners who delayed marriage until they attained the legal minimum age of marriage without their parents assent, the measure of marriage duration would be biased--downwards in the case of this example. This caveat qualifies the statement in the text regarding pregnancy at the date of marriage.

${ }^{9}$ For the 20-24 age group foreign birth is only significant at the $10 \%$ leve1.

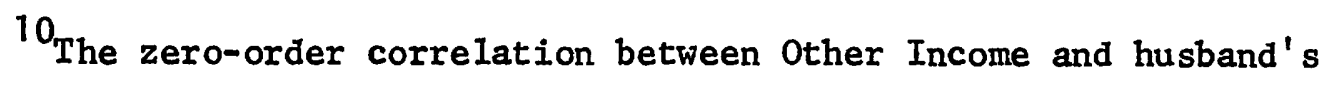
schooling is 0.307 , so that multicollinearity between these variables does not appear to be a serious problem.

11 The only coefficient which attains statistical significance at the better than $10 \%$ level is that for the 25-29 age group, where the coefficient is negative $[t=1.77]$. 
12 The probit equation used to compute the "Iambda" variables differed slightly from column (1) in that it included squared terms in husband's schooling and Other Income. Since these latter two variables were insignificant they are excluded from the regression reported in colum (1) of Table 3 .

13 The coefficient on the lambda variable depends on the covariance between the error terms in the labour force participation and childlessness regressions。

14 The zero-order correlation between the two lambda variables is approximately 0.52 for each subsample, so that multicollinearity does not appear to be a major problem. 
$\underline{\text { References }}$

Andrews, F. M. and R. C. Messenger

1973 Miltivariate Nominal Scale Analysis. Ann Arbor: Survey Research Center, Institute for Social Research.

Amemiya, T .

1981 "Qualitative response models : a survey." Journal of Economic Literature $19(4):$ 1483-1536.

Balakrishnan, T. R., G. E. Ebanks and C. F. Grindstaff

1979 Patterns of Fertility in Canada, 1971. A 1971 Census of Canada monograph. Ottawa: Statistics Canada.

Carliner, G., C. Robinson and N. Tomes

1980 "Female labour supply and fertility in Canada." Canadian Journal of Economics 13(1): 46-64.

Catsiapis, G. and C. Robinson

1982 "Sample selection bias with two selection rules: an application to student aid grants." Journal of Econometrics 18(2): 351-368.

Grindstaff, C. F., T. R. Balakrishnan and G. E. Ebanks

1981 "Socio-demographic correlates of childless: an analysis of the 1971 Canadian Census." Canadian Journal of Sociology 6(3): 337-351.

Gunderson, $\mathrm{M}$.

1979 "Earnings differentials between the public and private sectors." Canadian Journal of Economics 12(2): 228-242.

Heckman, J. J.

1979 "Sample selection as a specification error." Econometrica 47(1): 153-161.

Kyriazis, N.

1982 "A parity-specific analysis of completed fertility in Canada." Canadian Review of Sociology and Anthropology 19(1): 29-43. 
Michae1, R. T.

1973 "Education and the derived demand for children." Journal of Political Economy 81(2), Part II: s128-164.

Nerlove, M. and S. J. Press

1973 Univariate and Multivariate Log-Linear and Logistic Models, R-1306-EDA/NIH. Santa Monica: Rand.

Poston, D. L. Jr.

1974 "Income and childlessness in the United States: is the relationship always inverse?" Social Biology $21(3):$ 212-224.

Powers, J. A., I. C. Marsh, R. R. Huckfeldt et al

1978 "A comparison of logit, probit and discriminant analysis in predicting family size." American Statistical Association, Proceedings of the Social Statistics Section: 693-697.

Robinson, C. and N. Tomes

1982 "Family labour supply and fertility: a two-regime model." Canadian Journal of Economics 15(4): 706-734.

Rosenzweig, M. R.

1977 "The demand for children in farm households." Journal of Political Economy 85(1): 123-146.

Veevers, J. E.

1972 "Factors in the incidence of childlessness in Canada: an analysis of Census data." Social Biology 19(3): 266-274.

1979 "Voluntary childlessness : a review of issues and evidence." Marriage and Family Review 2(2): 1-26.

1980 Childless by Choice. Toronto: Butterworths.

Willis, R. J.

1973 "A new approach to the economic theory of fertility behavior." Journal of Political Economy $81(2)$, Part II: S14-64. 
Wolowyna, J. E.

1977 "Income and Childlessness in Canada: a further examination." Social Biology 24(4): 326-331. 


\section{Definitions of Variables}

\section{VARIABLE}

Age

Age squared

Marriage Duration = (Age 1971 - Age at first marriage)

Marriage Duration squared

Marriage Duration raised to the power $j(j=3,4,5)$

Education of Wife ${ }^{1}$

Education of wife squared

Education of Husband 2

Education of Husband squared

Family Income ${ }^{3}$ (in $\$ 10,000$ units)

Pamily Income squared

Other Income = (Family Income - wife's income from wages and salaries - wife's income from self-employment) in $\$ 10,000$ units

Other Income squared

$\begin{array}{ll}\text { MNEMONIC } & \text { MEAN } \\ \text { AGE } & 41.47 \\ \text { AGESQ } & -- \\ \text { MD } & 18.88 \\ \text { MDSQ } & -- \\ \text { MD } & \\ \text { YRSSCH } & -- \\ \text { YRSSCHSQ } & 9.48 \\ \text { YRSSCH } & -- \\ \text { YRSSCHSQ } & 9.70 \\ \text { FAMINC } & -- \\ \text { FAMINCSQ } & 0.998 \\ & -- \\ \text { OTHINC } & 0.890 \\ \text { OTHINCSQ } & --\end{array}$

\section{REFERENCE GROUPS}

Work Status :

Region:

Urban/Rural:

Religion:

Ethnicity:

Nativity:

Language of Home:

Migration Status 1966-71: NOTES: worked in 1970 and/or 1971

Ontario

resident in large urban area, pop $\geqq 30,000$

Protestant (Anglican, Baptist, Lutheran, Pentecostal, Presbyterian, or United Church)

British Isles (English, Irish, Welsh or other British Isles)

Native (Canadian) born

English

same dwelling or same city, town or municipality.

1. The Education of wife variable (YRSSCH) was created from the EDUCAT variable on the PUST. Codes $0-12$ were recorded as $0,4,6.5,9.5,11,12,13,13.5$, $14.5,15.5,17.5,19$ respectively. For individuals who completed their secondary schooling in NFL or Quebec, university entrance was assumed to require one less year of high school. For individuals who completed their schooling in Ontario, university entrance was assumed to require one more year of high school. The coding of education employed here corresponds quite closely with that used by Gunders on (1979, p. 236).

2. The Education of husband variable (YRSSCH) was created from the HEAD-ED variable on the PUST. Codes 1 - 9 were recorded as $0,5.5,9,11,12,13$, $13.5,15.5,19$ respectively. Adjustments were made for differences across provinces in university entrance requirements similar to those indicated in note 1 above.

3. The Total Family Income (FAMINC) was created from the USFAMINC variable on the PUST. Codes 2-28 were recorded at interval midpoints, loss of income was coded as $-\$ 500$, no income as $\$ 0, \$ 50,000$ or more as $\$ 65,000$.

4. Means reported for whole sample $(n=46,376)$, except for Education of Husband and Other Income were means reported for samples used in Table $2(n=44,572)$. 